\title{
La Familia Telerín: Connected Learning through Transmedia
}

\author{
Julián de la Fuente Prieto, María Ruth García-Pernía, \\ Sara Cortés-Gómez, Rut Martínez-Borda, \\ and Pilar Lacasa
}

University of Alcalá, Spain

DOI: https://doi.org/10.7358/ijtl-2017-002-prie

julian.fuente@uah.es
mruth.garcia@uah.es
sara.cortesg@uah.es
rut.Martínez@uah.es
p.lacasa@uah.es

ABSTRACT - Nowadays, transmedia storytelling has shaped new ways to produce children's content, in which the audience has an increasingly active role (Livingstone and Bovill 2013; Cortesi et al. 2015). The fruition of storytelling content through digital media allows to connect it with personal interests and school activities as well as to enhance the link between adults and children (Ito et al. 2013; Jenkins, Ito, and boyd 2015). The main goal of this paper is to analyze the new transmedia release of one the most successful and recognized TV cartoons all over Spain and Latin America: La Familia Telerín. Specifically, we want to discover how the cartoon was re-valued by the production company Anima Kitchen, and understand the role that transmedia storytelling played out in this regard. Adopting a digital anthropology approach (Horst and Miller 2012), our findings come from big data, a focus group and through a virtual ethnography. The findings provide us with a clear understanding about how transmedia storytelling supports social values, media skills and learning activities into the everyday life of children.

\section{INTRODUCTION}

The increasing significance of participation and other skills in the context of new media, along with the almost-permanent online presence of children on these media, has made the investigation of transmedia content in relation to younger generations more and more relevant to academia (CortésGómez, Martínez-Borda, and de la Fuente Prieto 2016; de la Fuente Prieto,

International Journal of Transmedia Literacy - 3 - December 2017

http: //www.ledonline.it/transmedialiteracy - Online ISSN 2465-2261 - Print ISSN 2465-227X 
Gómez, and Martínez-Borda 2016). In this article, we analyze how a transmedia universe based on a traditional television format (La Familia Telerín, which is more than 30 years old) has been designed in order to appeal to today's children, who are called to actively participate in the storyworld being created. Moreover, the purpose of the project is to explain how the transmedia storytelling is integrated into the tradition of the cartoon, generating new children's content that connects with personal interests and school activities, and enhances the link between adults and children.

In order to do so, we have selected as a case study one of the most successful and recognized TV cartoons of all times in Spain and Latin America: La Familia Telerin. This cartoon began in 1964 with a famous TV spot made by the pioneers in animation in Spain: Estudios Moro. This clip was used to differentiate children and adult content in TV programming for almost thirty years. Still today, this TV spot is one of the most remarkable children content in many countries, such as Spain, México, Uruguay, Chile, Venezuela, Costa Rica, Perú, El Salvador and Nicaragua. Recently, the production company Anima Kitchen has recovered this cartoon and will soon release new episodes about the Familia Telerín. Most importantly, it will do so by adopting a transmedia strategy.

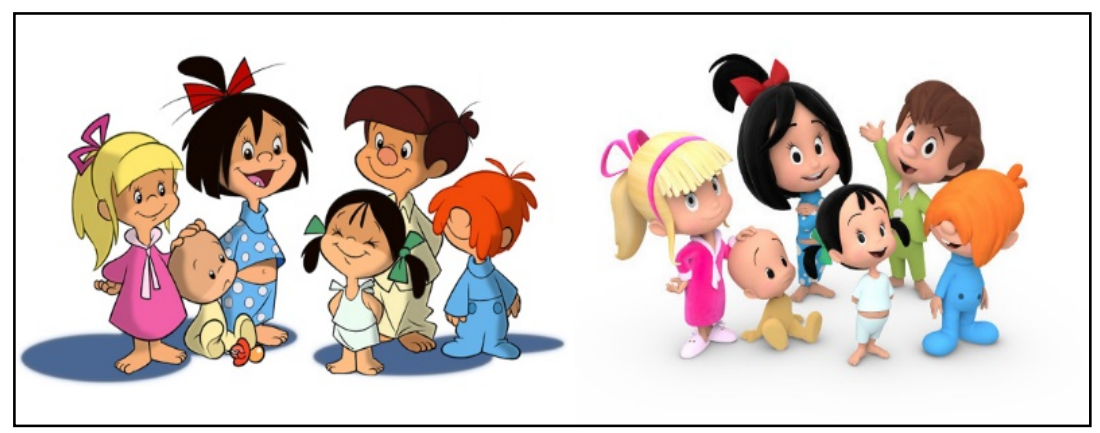

Figure 1. The original and the new Familia Telerin cartoons (Anima Kitchen 2016)

For this reason, the main aim of this paper is to understand how the reissue of a traditional and popular children cartoon, such as the Familia Telerín, is being transformed into a transmedia world and, specifically, a learning environment. We will focus on some specific issues regarding respectively the 
audience, storytelling, and literacy skills, keeping in mind the following goals:

To discover those connections between past and present content which allow the continuation of La Familia Telerín in and through the new media. Who is/are the current audience(s)? How do children and adults approach these contents?

To analyze how a traditional cartoon has become a new branded content by creating a transmedia storytelling. What strategies define this new transmedia product? How is the content distributed to and targeted for young audiences?

To evaluate the underliying literacy skills fostered and demanded by La Familia Telerín and its potential as a learning tool. How do the interests of the child audience connect with educational environments? What kind of skills are boosted by transmedia storytelling?

Before addressing these questions, it is useful to provide a brief survey of existing scholarly literature on the topic.

\section{THEORETICAL FRAMEWORK}

Three are the main axes around which research on transmedia culture is organized, and these will also guide the present discussion: 1) Young audiences: how to appeal to new and younger audiences and engage them through new media content ;2) Transmedia storytelling: the exploration of how content is spread across multiple platforms, allowing the participation of the audience; 3) Connected learning: the investigation of the synergies between formal and non-formal learning environments where children are able to learn in the 21st Century. Figure 2 schematizes the three points, while further below we delve more in depth into each one of them:

\subsection{Young audiences}

Children's content in mass media, such as television, was largely intended to entertain while establishing beliefs and attitudes. Today, these traditional media still try to amuse and teach at the same time. They are important means of socialization which, together with school institutions and the

International Journal of Transmedia Literacy - 3 - December 2017

http: //www.ledonline.it/transmedialiteracy - Online ISSN 2465-2261 - Print ISSN 2465-227X 
family, exercise the senses, form feelings and social imagination (Gitelman 2006; Hayles 2012). So, what happens to this children-oriented content with the advent of new media and technologies?

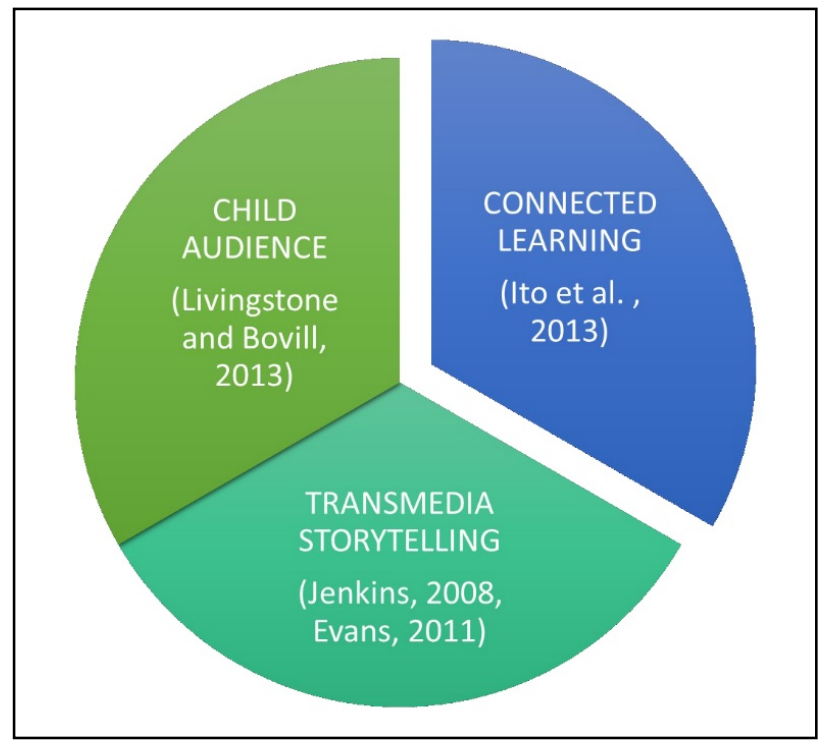

Figure 2. Theoretical framework

This content increasingly responds to new forms of consumption, especially forms where the audience takes on an active role. New environments, displays and ways of acting are in an undifferentiated and often simultaneous multi-consumption of different media, especially audiovisual (Livingstone and Bovill 2013, Stein 2015). This tendency both demands and creates a kind of audience that, in addition to consuming content, is an effective producer of meaning. In other words, we witness the emergence of active and sometimes hyperactive audiences, capable of building unique synergies with the new media.

Children have the control on what to see, when, and where because of the diversity of content and the possibility of approaching it through different channels. Hearings make sense to services and interactive potential of media and technology. People are what they really give meaning to the 
content according to individual or group needs and desires (Cortesi et al. 2015; Jenkins, İto, and boyd 2015) This idea changes the conception of a passive audience in the media, by the approach of an active audience. In this sense, we try to connect these functions with our case study, La Familia Telerin: a valuable children's content in the past, now adapted based in transmedia storytelling.

\subsection{Transmedia storytelling}

We have talked about transmedia, a phenomenon that involves the creation of content and characters across multiple media platforms. In the ideal form of transmedia storytelling, "each medium does what it does best" (Jenkins 2008, 98). According to Jenkins, most transmedia content serves one or more of the following functions: 1) to propose a backstory through scattered elements across multiple platforms; 2 ) to map the world by gathering together multiple pieces that come together in interactive contexts; 3 ) to provide varied character's perspectives on the action; 4) to enhance a deeper engagement of the audience through participation in the storyworld.

From this social construction of worlds and meanings, the narrative dimension of our daily experience also emerges. In practice, this means that the traditional barriers between fictional, virtual or online contents regarding our perception of reality disappear (Ryan and Thon 2014; Hatavara et al. 2015). Transmedia storytelling allows us to relate the different narrative worlds that we explore each day in a unified experience through the media.

Therefore, we want to understand not only the role of new media in children's social life, but also how these media cooperate with other media, as well as the interactions they promote with increasingly active audiences. More specifically, by discussing how a classic TV program can become a transmedia learning environment for today's children, we will explore the language of media as forms of expression and the discursive practices, which derive from its use (Scolari 2009; Evans 2011). 


\subsection{Connected learning}

The search for an educational approach that takes into account the sociocultural context of learning refers to media literacy and collaborative learning (Lacasa 2013; Levy 2015). In fact, current debates stress the need to define media literacy as more than mere reading and writing competences in the context of multilingual technologies and media (Kress 2010; Buckingham 2013). This leads us to seek a methodology for media education that is not limited to functional literacy, but also capable of fostering teaching/learning processes within today's media ecology.

One approach deriving from such understanding is the so-called "connected learning" (Ito et al. 2013) that proposes the creation of learning contexts in which the areas of personal interest, the interaction between peers and academic life are related. As Ito et al. $(2013,3)$ point out, "connected learning is realized when a young person is able to pursue a personal interest or passion with the support of friends and caring adults and is in turn able to link this learning and interest with other areas of their life." Like other sociocultural models, connected learning focuses on the will to establish open, collaborative and meaningful learning, whose main contextual frame of action is human culture.

\section{METHOD}

According to previous research that we conducted (Lacasa, MartínezBorda, and Mendez 2013), to take into account the sociocultural context is especially useful for analyzing and interpreting data from the design of transmedia content (Ciancia 2015). This is why we opted for a qualitative methodology for the analysis of our case study, thus allowing us to deepen the interpretation of the data within its context (Vittadini et al. 2014).

In so doing, the research also extends the traditional analysis of children's television content and it comes to include the point of view of transmedia culture (Delgado 2015). This means, in other words, to move beyond television as the privileged medium of discussion and to question the narrative exclusivity of cartoons as well as the merely passive role of the audience. Our goal is to understand transmedia content as a holistic experience (Pratten 2011) designed to be interactive with the environment of those children who participate in this same experience. 
As a result, one of the current approaches for studying the sociocultural facts eminently produced on the Internet is Digital Anthropology (Horst and Miller 2012; Pink et al. 2015), a methodology that equally and mutually considers what is done online with what is done offline (Pink, Ardèvol, and Lanzeni 2016). More specifically, we resorted to a three-phase methodology for the collection of data:

Big Data (Borgman 2015). Firstly, we analyzed impact data on social networks, helping us to weigh the case study and guiding the qualitative analysis. These data will be used directly in the triangulation of the evidences collected through the other techniques.

Virtual ethnography (Boellstorff 2012). Secondly, we described the materials present in the media that refer to our case study. The way to approach these data will be from the observation and description of the researchers.

Focus group (Kamberelis and Dimitriadis 2014). Thirdly, we conducted an in-depth interview with those responsible for the transmedia design of the case studied. In this way, it was possible to validate the findings gathered during the second stage.

After the data collection, the research team analyzed all materials using NVivo, which is a precious tool for processing audiovisual materials, and transcribe verbal discourse. Then, these texts are categorized to interpret discourse and explain processes (Gee 2014).

\section{RESUltS}

Our analysis follows the three axes identified above: audience, storytelling and literacy. First of all, we will focus on the activation impact in terms of hearings of child and adults. Secondly, we describe the transmedia strategy comparing both storytelling and schedule plan. Lastly, we examine content in order to categorize social values, media skills and learning activities that we can find in it.

Despite this is an ongoing research, we are ready to provide preliminary results from the beginning of the transmedia relaunch of La Familia Telerin. We will focus on data collected from September 2015 to March 2016. The focus group took place in Madrid on March 1, 2016 with the creative team of Anima Kitchen, led by Víctor M. López, who is also re-

International Journal of Transmedia Literacy - 3 - December 2017

http: //www.ledonline.it/transmedialiteracy - Online ISSN 2465-2261 - Print ISSN 2465-227X 
sponsible of other well-known children's media products such as Pocoyo (Zinkia 2005).

\subsection{Audience activation}

The relaunch of La Familia Telerin was on August 25, 2015 with the reissued of the TV spot "Vamos a la cama" (Going to sleep) in prime time on Mexico's Televisa channel. This new version repeats in essence the same sequence and song with a 3D cartoons. Meanwhile, a YouTube channel opened with a foreseeable degree of international impact. During the first six months La Familia Telerin accumulated more than 200, 000 subscribers and 80 million views on YouTube (Figure 3).

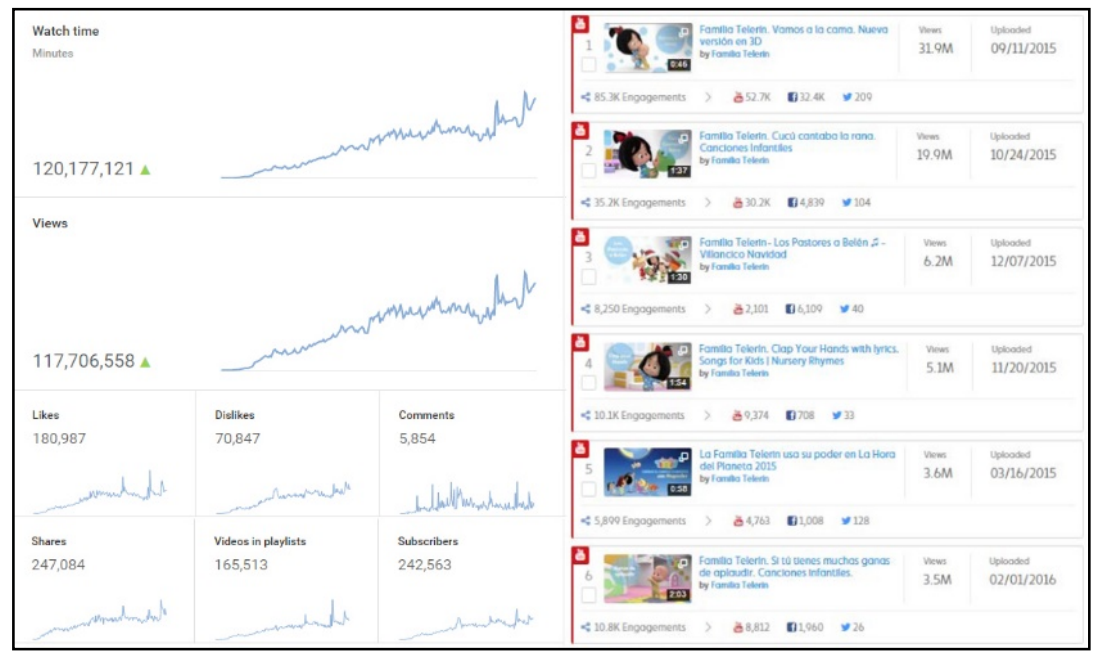

Figure 3. Statistics from the official YouTube Channel (source: YouTube Analytics)

Most remarkably, these numbers were achieved by updating only six videos of an average duration of less than two minutes. From October 2015 to February 2016 the subscribers and views increased by 100\%. Specially, January 2016 when the official channel got into "Education-Children Songs" Ranking: 


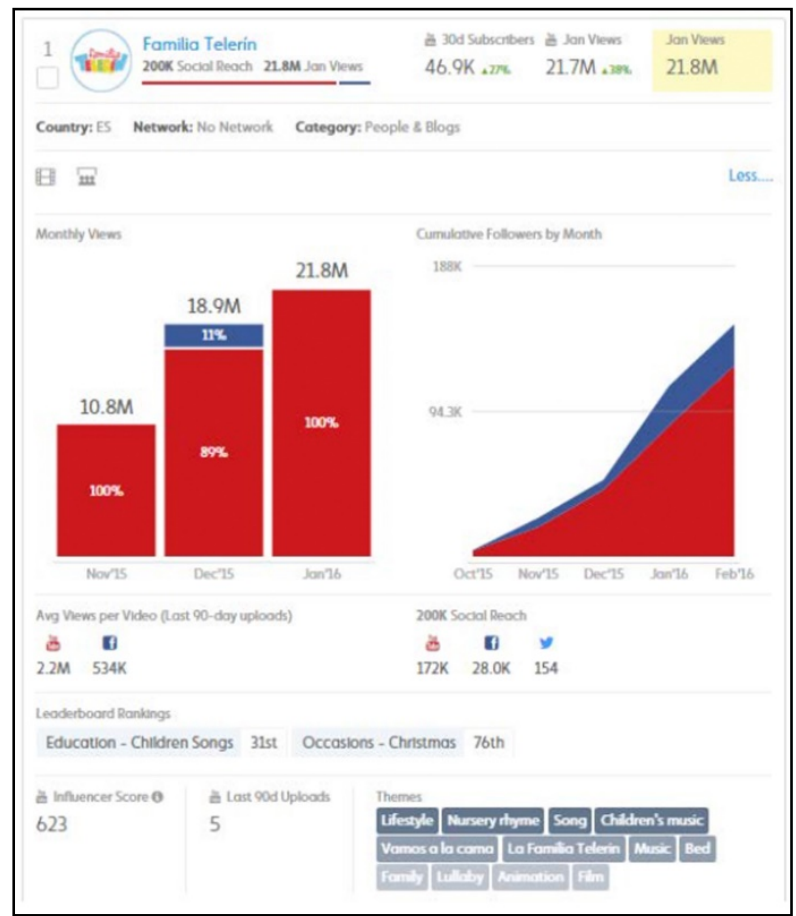

Figure 4. Leaderboard Familia Telerin in Education-Children Songs rankings

It is hard to explain such growth in consideration of the minimum amount of content uploaded, unless we connect it to the media tradition of $\mathrm{La} \mathrm{Fa}$ milia Telerin and its TV audiences. Therefore, the case study is sufficiently justified given the representativeness of the phenomenon.

\subsection{Transmedia plan}

We argue that La Familia Telerin fits perfectly into the transmedia storytelling guidelines proposed by Henry Jenkins (2008). In fact: 1) it offers a backstory with traditional content; 2) it maps a storyworld with different formats across media; 3 ) it expands the characters' perspectives through social media; 4) it engages audience participation with the interaction be- 
tween adults and children. In fact, we can find out more on these aspects by exploring how the relaunch of La Familia Telerin has been planned by Anima Kitchen.

First of all, it is important to highlight that the release of the new $\mathrm{La}$ Familia Telerin entails a roll out plan of three years. The new content has been distributed since 2015 in various ways: through websites, social networks, applications for mobile devices, and so on (see the infographic in Figure 5).

In Mexico, this planning included also TV broadcasting and licenses of merchandising, although these were not the primary content on which the relaunch was based. Indeed, Anima Kitchen prioritized a distribution of the new La Familia Telerin through social media and adopting a native transmedia storytelling. There is not a privileged medium in this transmedia storytelling: all of them contribute to the storyword with the same importance. In fact, Anima Kitchen's main focus was not much on the media ecosystem but on the audience, i.e. children:

In the Figure 6, we can see how the new content of La Familia Telerin manages to cover the typical media routine of kids. From early morning to bedtime, at school or during leisure time, there is always a content adapted to the medium and place where it will be watched. Therefore, we can consider the content planning of La Familia Telerin as a true transmedia experience.

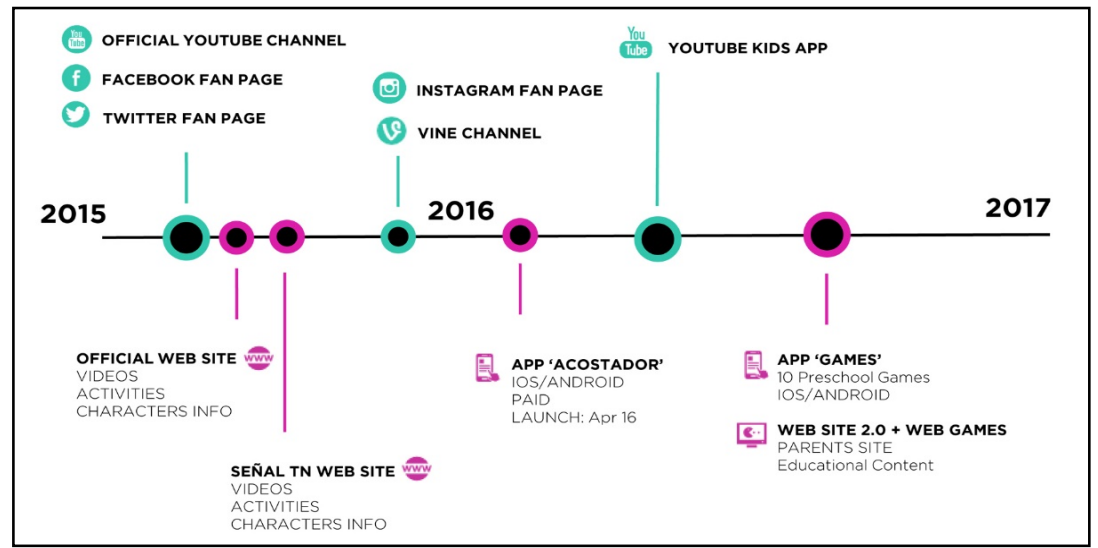

Figure 5. Digital strategy of La Familia Telerin (source: Anima Kitchen) 


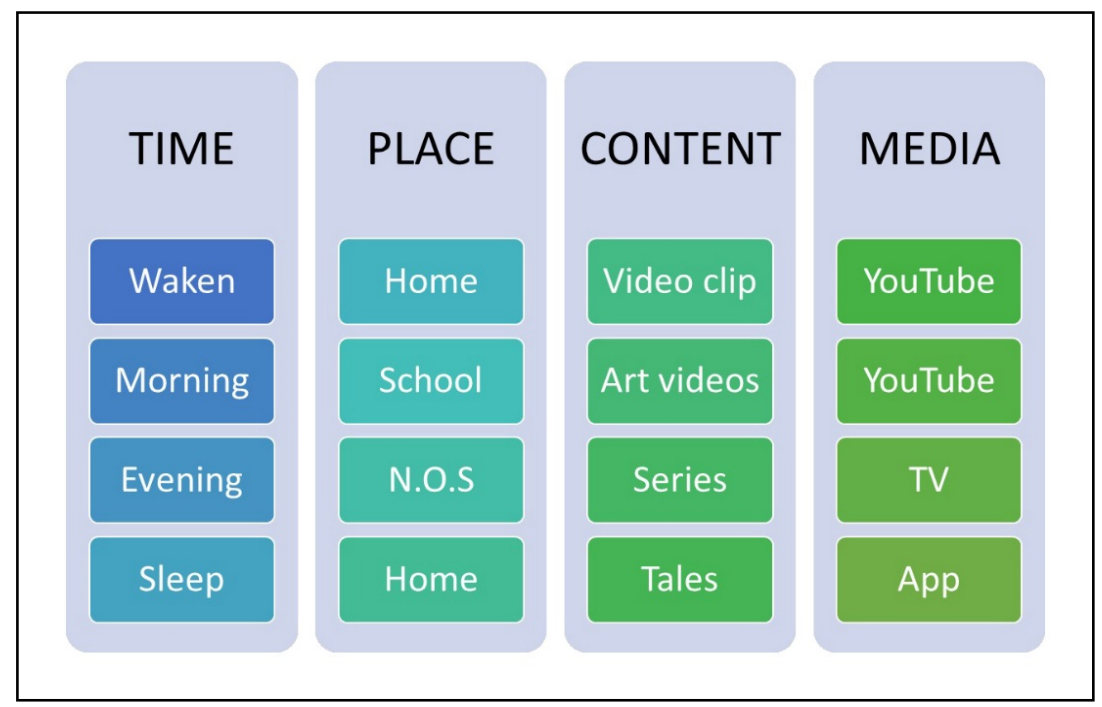

Figure 6. Transmedia experience of La Familia Telerin (source: Anima Kitchen)

\subsection{Content evaluation}

Now, we are going to examine the new content of La Familia Telerin and connect it to the principles of connected learning (Ito et al. 2013). After a review of digital ethnography, we have eventually come up with a group of skills that this content has proved to contribute to develop. Among others, we refer to traditional culture, social values and media participation.

One example of culture-related skills can be found in the video clip Las Mañanitas (Figure 7, Anima Kitchen 2016). This is a traditional Mexican song that is usually sang at birthday parties. The narrative of the video connects this song with the first birthday party of the youngest of $\mathrm{La} \mathrm{Fa}$ milia Telerin. In so doing, this video introduces kids to family traditions in Latin America. 


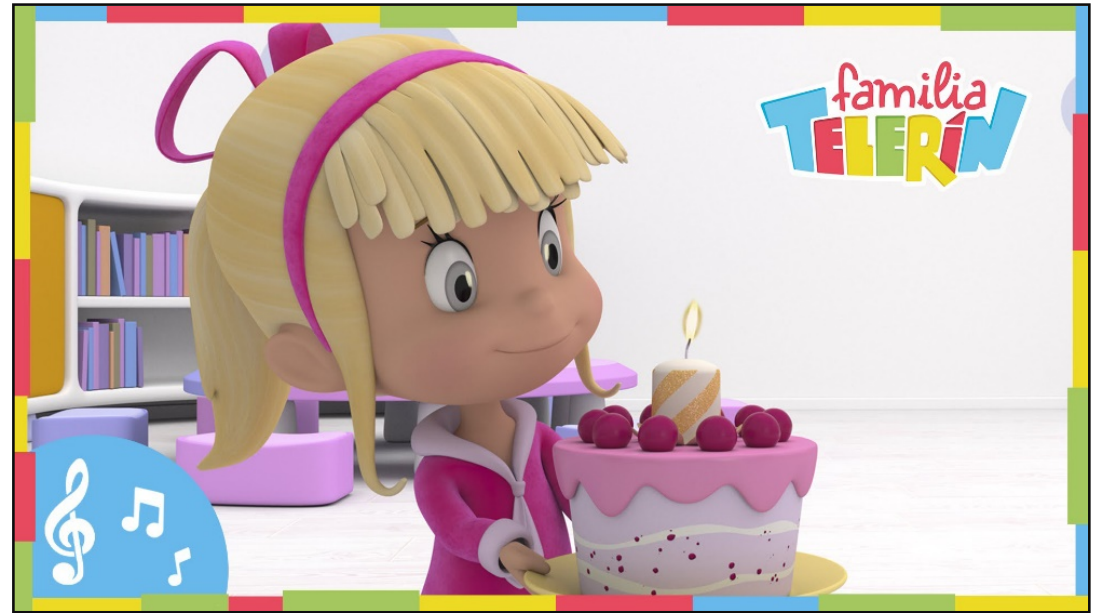

Figure 7. Thumbnail of Las Mañanitas in YouTube (source: Anima Kitchen)

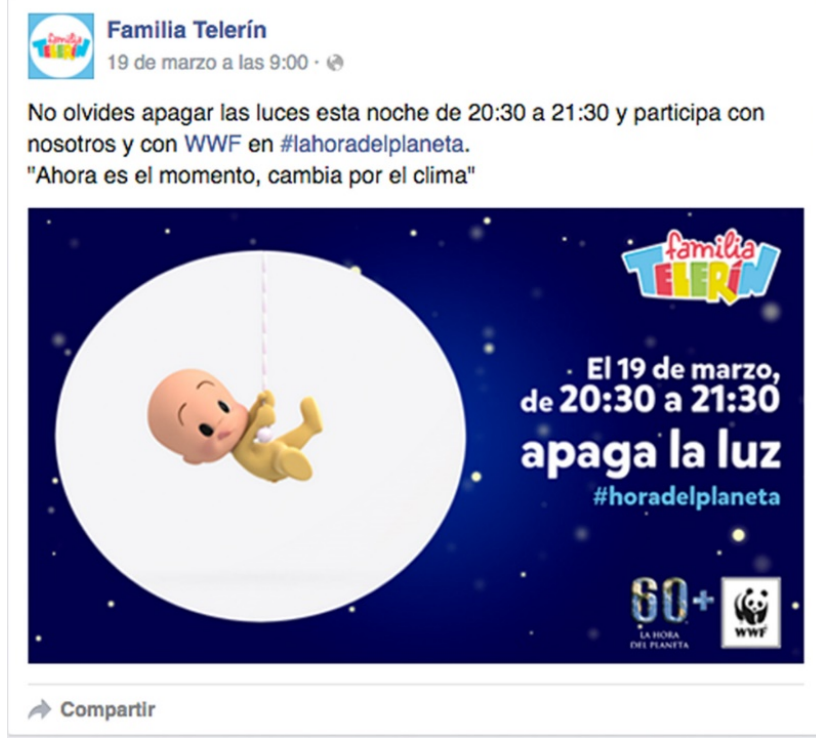

Figure 8. Facebook post supporting La Hora del Planeta (source: Anima Kitchen)

International Journal of Transmedia Literacy - 3 - December 2017 http: //www.ledonline.it/transmedialiteracy - Online ISSN 2465-2261 - Print ISSN 2465-227X 
Another example of skills that La Familia Telerin contributes to develop is related to social values. In March 2016 Anima Kitchen decided to work together with the WWF campaign "The hour of the planet". To do this, it depicts the characters of La Familia Telerin in everyday situations while they are involved in environmentally sustainable actions. The ad, which reached about 4 million people on Facebook, is directed to children, but especially to adults.

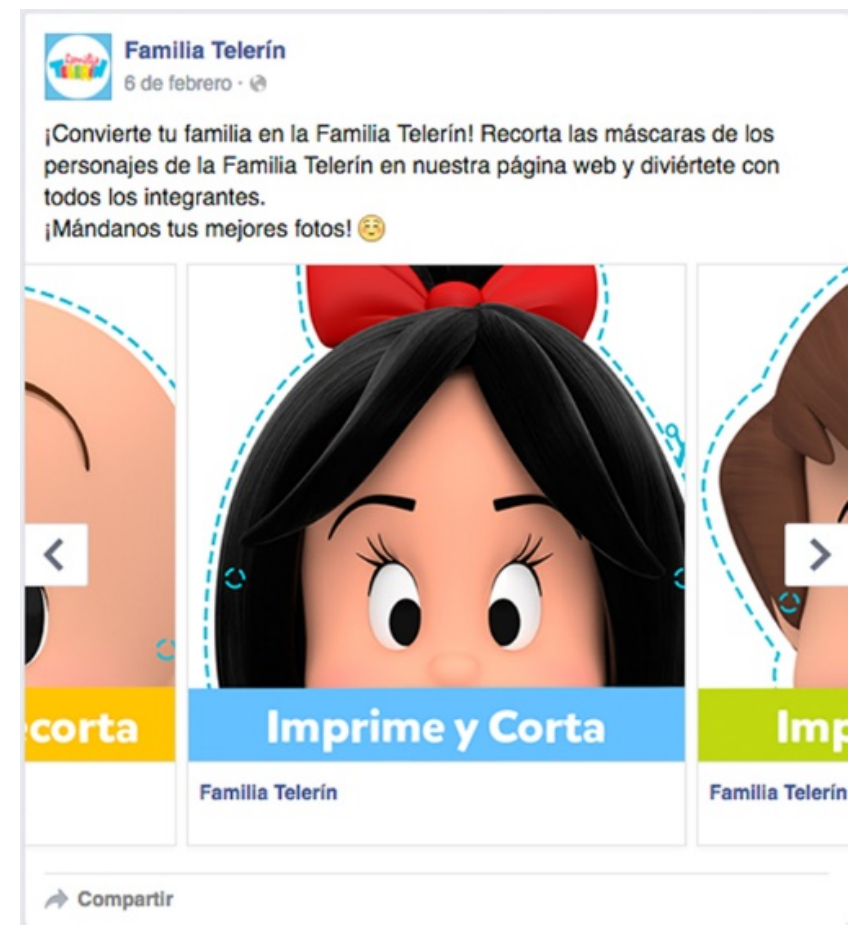

Figure 9. Participatory activities with La Familia Telerin (source: Anima Kitchen)

Lastly, we can find examples of skills connected with school activities. Through social networks, creative activities such as crafts or photography are promoted. The most important aspect to note is that to be encouraged is a collaborative performance of all these activities by children or adults

International Journal of Transmedia Literacy - 3 - December 2017 http: //www.ledonline.it/transmedialiteracy - Online ISSN 2465-2261 - Print ISSN 2465-227X 
alike. In this way, that it is also called to share the creations through these same social networks, encouraging active and meaningful participation through the media.

All these examples are part of a learning process where cultural traditions, social commitment and media participation are enhanced by transmedia storytelling. In this respect, La Familia Telerin brings learning opportunities provided by digital media, cultural tradition and social values together and it contributes to spread the synergies among them across various contexts both offline and online.

\section{CONCLUSION}

Through the example of the cartoon La Familia Telerin, this article showed how a traditional media content can be designed nowadays to be applied also to new media. Notably, we highlighted the extent to which the success of this transmediation depends on the interaction between children and adults. Moreover, we explored how the relaunch of La Familia Telerin managed to promote cultural and social values as well as the fostering of a learning environment. More specifically, we could summarize our final remarks as follows:

La Familia Telerin has been a well-known cartoon for over thirty years now. Because of that, nowadays adults play an important role in conveying to younger generations the recognition and emotional attachment to this cartoon. Thus, we've noted the success of the transmediated content to be dependent upon a solid link between adults and children.

Transmedia storytelling is an extraordinary resource for engaging audiences. In this respect, the transmediaton of La Familia Telerin aptly takes into account children's daily routines and everyday contexts. Therefore, the new La Familia Telerin is one of the very first transmedia content in Spanish that has been designed beyond mass media.

Connected learning allows the mixing of children's interests, friendships and learning goals. Clearly, La Familia Telerin provides an excellent example of content that introduces values, skills and learning activities specific to school settings, while maintaining the quality and features of a commercial animation production. However, it is also necessary to improve the participation of children in La Familia Telerin by making meaningful contributions and fandom activities. 


\section{REFERENCES}

Boellstorff, Tom. 2012. Ethnography and Virtual Worlds: A Handbook of Method. Princeton: Princeton University Press.

Borgman, Christine L. 2015. Big Data, Little Data, No Data: Scholarship in the Networked World. Cambridge: MIT press.

Buckingham, David. 2013. "Challenging Concepts: Learning in the Media Classroom”. Current Perspectives in Media Education: Beyond the Manifesto: 24. London: Roudledge.

Ciancia, Mariana. 2015. "Transmedia Design Framework. Design-Oriented Approach to Transmedia Research". International Journal of Transmedia Literacy 1(1): 131-145.

Cortés-Gómez, Sara, Rut Martínez-Borda, and Julián de la Fuente Prieto. 2016. "Contribución de las Redes Sociales a la creación de narrativas transmedia a partir de las series de ficción en Televisión”. Comunicación y Hombre 12: 153-176.

Cortesi, Sandra, Urs Gasser, Gameli Adzaho, Bruce Baikie, Jacqueline Baljeu, Matthew Battles, Jacqueline Beauchere, Elsa Brown, Jane O Burns, and Patrick Burton. 2015. Digitally Connected: Global Perspectives on Youth and Digital Media. Berkman Center Research Publication No. 2015-6

De la Fuente Prieto, Julián, Sara Cortés Gómez and Rut Martínez-Borda. 2016. “El inicio de la televisión transmedia en España: TVE y 'Víctor Ros'”. Revista de la Asociación Española de Investigación de la Comunicación 3 (6): p. 28-42.

Delgado, Melvin. 2015. Urban Youth and Photovoice: Visual Ethnography in Action. Oxford: Oxford University Press.

Evans, Elizabeth. 2011. Transmedia Television: Audiences, New Media and Daily Life. London: Routledge.

Gitelman, Lisa. 2006. Always Already New: Media, History and the Data of Culture: Cambridge: MIT Press.

Hatavara, Mari, Matti Hyvarinen, Maria Makela, and Frans Mäyrä, eds. 2015. Narrative Theory, Literature, and New Media: Narrative Minds and Virtual Worlds. London: Routledge.

Hayles, Katherine. 2012. How We Think: Digital Media and Contemporary Technogenesis. Chicago: The University of Chicago Press.

Horst, Heather A., and Daniel Miller. 2012. Digital Anthropology. London: Berg.

Ito, Mizuko, Kris Gutiérrez, Sonia Livingstone, Bill Penuel, Jean Rhodes, Katie Salen, Juliet Schor, Julian Sefton-Green and S. Craig Watkins. 2013. Connected Learning: An Agenda for Research and Design. Chicago: Digital Media and Learning Research Hub. 
Jenkins, Henry. 2008. Convergence Culture la Cultura de la Convergencia de los Medios de Comunicación. Barcelona: Paidós comunicación.

Jenkins, Henry, Mizuko Īto and Danah Boyd. 2015. Participatory Culture in a Networked Era: A Conversation on Youth, Learning, Commerce, and Politics, Cambridge: Polity Press.

Kamberelis, George, and Greg Dimitriadis. 2014. "Focus Group Research: Retrospect". in The Oxford Handbook of Qualitative Research. 315-341. Oxford: Oxford University Press.

Kress, Günther R. 2010. Multimodality: A Social Semiotic Approach to Contemporary Communication. London: Routledge.

Lacasa, Pilar. 2013. Learning in Real and Virtual Worlds: Commercial Video Games as Educational Tools. London: Springer.

Lacasa, Pilar, Rut Martínez-Borda, and Laura Mendez. 2013. "Media as Practice: Narrative and Conceptual Approach for Qualitative Data Analysis". Studies in Media and Communication 1(2), 132-149.

Levy, Pierre. 2015. "Collective Intelligence for Educators". Educational Philosophy and Theory 47(8): 749-754.

Livingstone, Sonia, and Moira Bovill. 2013. Children and Their Changing Media Environment: A European Comparative Study. New York: Routledge.

Pink, Sarah, Elisenda Ardèvol and Débora Lanzeni. 2016. Digital Materialities: Design and Anthropolog. London: Bloomsbury Academic.

Pink, Sarah, Heather Horst, John Postill, Larissa Hjorth, Tania Lewis and Jo Tacchi. 2015. Digital Ethnography: Principles and Practice. London: Sage.

Pratten, Robert. 2011. Getting Started with Transmedia Storytelling. London: Create Space.

Ryan, Marie-Laure and Jan-Noël Thon. 2014. Storyworlds across Media. Lincoln: University of Nebraska Press.

Scolari, Carlos Alberto. 2009. "Transmedia Storytelling: Implicit Consumers, Narrative Worlds, and Branding in Contemporary Media Production". International Journal of Communication 3(21): PAGES

Stein, Louisa Ellen. 2015. Millennial Fandom: Television Audiences in the Transmedia Age. Iowa City: University of Iowa Press.

Vittadini, Nicoletta, Simone Carlo, Øystein Gilje, Ditte Laursen, Maria Francesca Murru and Kim Christian Schrøder. 2014. "Multi-Method and Innovative Approaches to Researching the Learning and Social Practices of Young Digital Users". International Journal of Learning 4 (2): 33-45.

International Journal of Transmedia Literacy - 3 - December 2017

http: //www.ledonline.it/transmedialiteracy - Online ISSN 2465-2261 - Print ISSN 2465-227X 